For by the conditions obtained $\theta$ is the same in both $\mathrm{A}$ and $B$. Hence $S=\left(\frac{C}{\bar{C}_{1}}\right)^{2}=\left(\frac{r_{1}}{r}\right)^{2}$, where $r_{1}$ and $r$ are the resistances of the two circuits. It is obviously unnecessary to make the resistances, and the masses of liquids, equal, but the equation is thus simplified. If a smaller mass of water, $m$, be taken, then $\mathrm{S}=\frac{m}{\mathrm{M}} \cdot\left(\frac{r_{1}}{r}\right)^{2}$, thus increasing the delicacy of the method.

Since in the adjustments a considerable amount of time would be necessary to allow the calorimeters to attain thermal equilibrium after each trial, the following modification may prove more simple and more practical :-

The calorimeter B is arranged so that by a switch-key, $C$, the current can be diverted through a wire of exactly equal resistance, $b$, so that the current is the same by either path. The resistance from $D$ to $E$ is the same either way. The key $\mathrm{F}$ is pressed down for a time, $t$,

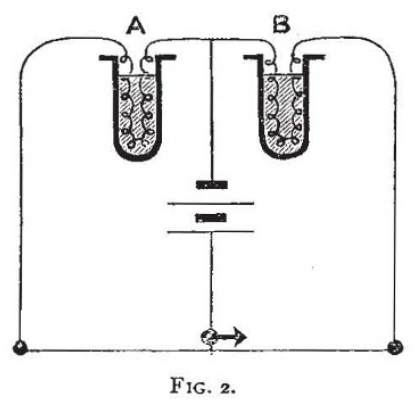

until the needle is largely deflected; then the current is switched from B and passed through $A$ alone, until the needle is just brought back to zero, in total time, T. Then, neglecting for the present the slight error due to cooling, in $\mathrm{A} \ldots \theta \mathrm{M}=\frac{\mathrm{C}^{2} \mathrm{RT}}{\mathrm{J}}$, in $\mathrm{B} \ldots \theta \mathrm{MS}=\frac{\mathrm{C}^{2} \mathrm{R} t}{\mathrm{~J}}, \therefore \mathrm{S}=\frac{t}{\mathrm{~T}}$. Since $\mathrm{T}$ and $t$ can both be made large, this should give very accurate results. It is evidently especially applicable to the measurement of the rate of increase of specific heat with temperature, since the liquids may have any initial temperature.

In conclusion, I may say that I should not have published this method in such an incomplete state, and unsupported by experiment, but I noticed to-day (September 5) that Profs. Stroud and Gee intend to read a paper before the British Association on "A Null Method in Electro-Calorimetry," and it is possible this may refer to a similar method. GEORGE N. HUNTLY.

\section{THE HESSIAN FLY.}

I AM sorry to say that reports from correspondents acquainted with the attack of the Hessian fly show its presence now in an almost continuous line along the northern and eastern coast from Cromarty on the Moray Firth in Scotland down to Kent.

I have this morning received specimens of the puparia from the parish of Urquhart, in Morayshire, the most northerly locality from which I have at present received the so-called "flax-seeds."

The amount of presence varies very much. In the locality above mentioned (that is, the district from Aberdeen to Cromarty), the traces of attack are reported as to be found from 25 to 30 miles inland, but the injury slight, not more than one straw in fifty being affected, and the grain of fair quality. It is severe in some parts of Perthshire, and is found alse in the eastern counties adjacent.
In East Lothian, Haddington, and Berwickshire attack is only reported from a few places at present, and in Northumberland from one locality.

Beginning again on the two sides of the Humber the attack widens much in area as it is traced south. It passes through Lincolnshire and Cambridgeshire, touching an easterly part of Northamptonshire, till it extends over the district commonly known as the eastern counties, including besides great attack in Hertfordshire, and some in Bedfordshire; and it also occurs in Kent.

In the southerly or westerly parts of England it occurs at Lymington and Petersfield in Hampshire, and to a considerable extent near the College of Agriculture, Downton, near Salisbury : and I have one report of it from near Bridgwater, and it also occurs at Goring Heath, Oxfordshire.

'The above localities are where I know of its presence from specimens sent to myself, or, in a few cases, from information given me by correspondents whom I know to be acquainted with the appearance of the puparium, and the characteristics of the attack.

It very likely may occur elsewhere, but I am only just giving a general sketch of extent of infested area from personal knowledge.

It strikes me as a very curious point that the attack should so markedly cling to the sea-side, excepting in a few isolated instances, or where the inland area is continuous with the sea-side district.

It is very satisfactory to observe that although the season has been so altogether extraordinarily favourable to various kinds of insects affecting corn-stems, yet that in very many instances reported to me the injury caused to wheat by Hessian fly has been slight

On this fact I venture to think we may ground a hope that, either from the varieties of wheat which we use being kinds suited to do what is called "resist" attack, or from circumstances of our cultivation, we may find that our wheat at least does not suffer as much as in some other countries.

Also the enormous prevalence of the two stem attacks caused respectively by the corn sawfly (Cephus pygmaus), and by the dipterous fly, the Chlorops taniopus (attacks which far exceed in amount any which have been brought under my notice as caused by these insects), give a hope that the climatal circumstances which usually prevail here will have an effect in checking the attack of the Cecidomyia destructor, as well as the above-named crop pests, as we see that all three kinds have been exceptionally thriving in the exceptional heat and drought.

It is unnecessary to point out to your highly informed and thinking readers that the statements now appearing of the Cecidomyia destructor having been a corn pest in this country for many years have not the slightest foundation. ELEANOR A. ORMEROD.

\section{THE BRITISH ASSOCIATION.}

\section{MANCHESTER, Tuesday Evening.}

$A$ BOUT the success of the Manchester meeting there seems to be only one opinion. In mere numbersthe most popular gauge of success-it has by several hundreds surpassed all former meetings; the number of tickets sold very closely approaches 4000 . As a natural result, the amount of money collected and available for the purposes of research is unprecedentedly great, as will be seen by the list of grants which have been allotted to the various Committees. The great increase in attendance over all former years is to a considerable extent due to the large number of foreign visitors, who have formed a marked and prominent feature of the present meeting. In the proceedings of nearly every Section the representatives of foreign science have taken an active 
part, with the result that the time of the whole meeting has been more intensely scientific than in the case of any previous meeting. This has been especially shown in the case of the important discussions which had been arranged for, and which most of them bore the character of real debate; the only exception, we believe, being the case of electrolysis, in Sections A and B, the "discussion" consisting mostly of the reading of a series of papers. Quite otherwise, however, was it with the discussions on heredity, introduced by Prof. Lankester, and on the cell theory, introduced by Prof. Schäfer, in Section A -discussions in which the subjects were threshed out very thoroughly. To some extent it is generally conceded that the great mixture of foreigners has to some extent solved the problem of an International Scientific Congress, which in any formal way is generally considered impracticable. Their presence here has certainly added a stimulating variety to the meeting, and the honour has been duly appreciated by the Corporation and citizens of Manchester. The foreigners have all been hospitably entertained as guests, and there have been not a few special entertainments got up for their special behoof. At the great dinner to be given to-morrow by the Mayor and Corporation nearly half of the guests will be foreigners. One of the pleasantest gatherings of the meeting was at a little dinner given on Sunday night by a few of the biologists to a select few of their foreign co-workers, especially botanists, at which De Bary delighted everybody present.

The number of papers read at this meeting has been quite comparable with its other exceptional features. Sections that have never split before have been compelled to split now. Biology, though it has thrown off Section $\mathrm{H}$, has this year split into two sub-sections,-Botany and Physiology,-and there is even some fear, perhaps hope, that these divisions may become permanent. On Saturday every Section met except $\mathrm{E}$, and to-morrow the majority will have to sit close up to the General Committee-meeting. Out of all this rush of papers no doubt some good comes, but most of those interested in the welfare of the Association admit that it would be well to moderate it, or perhaps still more completely to organize it. For one thing the custom of reading one paper in several Sections is greatly to be deprecated, and this year it has been carried still further than ever, greatly to the indignation of those Sections which had to submit to hearing the story retold. This came to a crisis in Section E, where an eminent geologist, who condescended to read a paper to some extent already given to his own Section, was told in almost so many words that Section $\mathrm{E}$ had no time to listen to geological lectures. Here indeed the battle between the geologists and geographers was fought out, greatly it was thought to the discomfiture of the former, who are loth to think that there is anything worthy of the name of geography outside of their own lines.

In spite of the persistently unfavourable weather, the public lectures have been quite successful. The lecture on the rate of explosions by Prof. H. B. Dixon kept a large audience intensely interested from beginning to end ; and nothing could be more striking and instructive than his experiments, some of which were on a gigantic scale. Equally attractive was the lecture to working men on Saturday evening on electricity by Prof. George Forbes. The biggest audience of any, however, assembled in the Free Trade Hall on Monday evening to listen to Sir Francis De Winton's lecture on exploration in Central Africa. The audience was evidently a popular one, and the lecturerhad the warmest reception. Unfortunately, the lantern used to show maps and pictures on the screen was rather a failure. Distinctly popular as it was, probably even the specialists were glad to get a convenient summary of recent work in Central Africa, pleasantly conveyed.

The address of the President of the Association, Sir Henry Roscoe, was very numerously attended. Sir
Henry was evidently audible all over the place, and his reception, as might have been expected, was enthusiastic.

Manchester is rather badly off for excursion places, and on Saturday, we believe, quite as many people spent the day in Manchester as elsewhere. Indeed, most of the Sections were so busy with work that they had no time to think of play. The little dredging excursion was joined in by about fifty men, who all seemed highly satisfied with the results, in spite of the weather. One of the most popular of the coming excursions will be that to the Isle of Man from Friday to Tuesday, under the guidance of Prof. Boyd Dawkins. There is also some talk of an excursion to the Lakes, but the weather does not encourage holiday enterprise in so notoriously rainy a region.

One popular and distinctly useful feature in connexion with the present meeting has been the Anthropometric Laboratory which has been established in connexion with Section H, under the care of Dr. Garson and Mr. Bloxam. It has been very largely frequented by the members of the Association, who have had themselves weighed, measured, and tested in a variety of ways. The object, we believe, is to obtain data from the most cultured classes to compare with those collected by Mr. Francis Galton, at South Kensington, from all and sundry. The result, it is expected, will be highly interesting.

We have already referred to the very varied exhibition which has been arranged in the galleries around the attractive reading-room. This has received various additions during the week. Prof. Boyd Dawkins shows some very instructive exhibits in various rooms belonging to the Geological Department of Owens College, including William Smith's first geological map and an autograph letter. Another exhibit deserving mention is the collection of wax models, illustrating vertebrate morphology and embryology, shown by Prof. His, of Leipzig, on behalf of Dr. A. Ziegler, of Freiburg. Naturally the model of the Manchester Ship Canal has attracted much attention, but not more than the great variety of interesting anthropological exhibits, which include the collection of casts and photographs from Egyptian monuments contributed by Mr. Flinders Petrie.

Great complaints have been made of the way in which the Press has reported the proceedings of the meeting. This may partly be due, no doubt, to the fact that Parliament is still sitting and takes up much of the space of the papers; but is also to be ascribed to a larger extent to the fact that ordinary reporters are hardly equal to the work of the British Association. When there are printed abstracts the matter is simple enough, but when discussions have to be reported the failure is almost absolute. This is certainly to be regretted, as it could not but be of the greatest service to have such discussions widely circulated. Surely it is quite worth while for the Sections to organize adequate reporting arrangements for their own sake.

The next meeting, at Bath, will be presided over by Sir Frederick Bramwell. In 1889 the Association will meet in Newcastle, and it is expected that an invitation will come from Leeds for 1890 .

The following is the list of grants which have been made this year by the Association :-

\section{A.--Mathematics and Physics.}

Ben Nevis Observatory Electrical Standards ... Magnetic Observations Standards of Light ... Electrolysis Solar Radiation

Differential Gravity Meter Uniform Nomenclature in Mechanics

$$
\begin{array}{cc}
\ldots & \ldots \\
\cdots & \ldots \\
\cdots & \cdots \\
\cdots & \cdots \\
\cdots & \cdots \\
\cdots & \cdots \\
\cdots & \cdots \\
\text { Mechanics }
\end{array}
$$$$
\begin{array}{lllr}
\ldots & \ldots & \ldots & \multicolumn{1}{r}{50} \\
\ldots & \ldots & \ldots & 80 \\
\ldots & \ldots & \ldots & 15 \\
\ldots & \ldots & \ldots & 100 \\
\ldots & \ldots & \ldots & 50 \\
\ldots & \ldots & \ldots & 10 \\
\ldots & \ldots & \ldots & 10 \\
\ldots & \ldots & \ldots & 10
\end{array}
$$ 


\section{B.--Chemistry.}

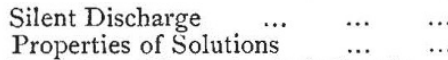

Recording Water Analysis Results ...

Influence of Silicon on Steel

Methods for Teaching Chemistry ...

Isomeric Naphthalene Derivatives ...

Action of Light on Hydro-acids ...

$$
\text { C. - Geology. }
$$

Sea Beach near Bridlington Geological Record

"Manure" Gravels of Wexford

Erosion of Sea Coasts

Erratic Blocks

Underground Waters

Palæontographical Society

Volcanic Phenomena of Japan

Pliocene Fauna of St. Erth

Carboniferous Flora of Lancashire and west Yorkshire ...

Volcanic Phenomena of Vesuvius ...

$$
\text { D. -Biology. }
$$

Zoology and Botany of the West Indies Flora of Bahamas

Development of Fishes, St. Andrews

Marine Laboratory, Plymouth

Migration of Birds

Flora of China

Physiology of the Lymphatic System

Marine Station at Granton ....

Peradenyia Botanical Station

Development of Teleostei

$$
\text { E.-Geography. }
$$

Depth of Frozen Soil...

$$
\text { F.-Economic Science and Statistics. }
$$

Precious Metals in Circulation Value of the Monetary Standard

$$
\text { G.-Mechanics. }
$$

Investigation of Estuaries by Models

$$
\text { H.-Anthropology. }
$$

Effect of Occupations on Development North-Western Tribes of Canada ... Prehistoric Race in the Greek Islands Anthropological Notes and Queries

$$
\text { Total .. }
$$

$\ldots$
$\ldots$
$\ldots$
$\ldots$

$\ldots$
$\ldots$
$\ldots$
$\ldots$

‥ 25

.. 100

Captain Sir Douglas Galton (one of the general secretaries) submitted the following report of the Council to the General Committee at the meeting held on the 3ist ult. :-

The Council have received reports during the past year from the general treasurer, and his account for the year will be laid before the General Committee this day. Since the meeting at Birmingham the following have been elected corresponding members of the Association : Dr. Finsch, Dr. O. W. Huntington, Dr. A. König, Lieut. R. Kund, Prof. Leeds, Prof. H. Carvill Lewis, Prof. John Trowbridge. The Council have nominated $\mathrm{Mr}$. Oliver Heywood a vice-president of the meeting at Manchester. An invitation for the year 1889 will be presented from Newcastle-upon-Tyne; but the invitations from Melbourne and Sydney have been withdrawn. The following resolutions were referred by the General Committee to the Council for consideration, and action if desirable :(a) "That the Council be requested to consider the question of rendering the reports and other papers communicated to the Association more readily acces- sible to the members and others by issuing a limited number of them in separate form or in associated parts, in advance of the annual volume." The Council, after careful consideration of the question, are of opinion that a certain number of copies of the more important reports presented to the Sections of the Association should be kept in stock and sold separately, the number of copies printed and the price of each report to be fixed by the secretaries after communication with the officers of the several Sections. (b) "That the Council be requested to consider the advisability of selling publicly the presidential addresses." The Council have considered the question, and are of opinion that it is desirable that printed copies of the addresses of the president and the presidents of Sections should be stitched together and sold ; that a number of copies, not exceeding rooo, should be printed; and that these should be placed on sale, at the price of one shilling, through agents or otherwise, as may be considered most suitable. (c) "That the Council be requested to consider the advisability of calling the attention of the proprietor of Stonehenge to the danger in which several of the stones are at the present time from the burrowing of rabbits, and also to the desirability of removing the wooden props which support the horizontal stone of one of the trilithons; and in view of the great value of Stonehenge as an ancient national monument, to express the hope of the Association that some steps will be taken to remedy these sources of danger to the stones." The Council have carefully considered the question, and having had the advantage of perusing the detailed report recently prepared by a deputation of the Wilts Archæological and Natural History Society on the condition of the whole of the stones constituting Stonehenge, are of opinion that the proprietor should be approached with the expression of a hope that he will direct such step; to be taken as shall effectually prevent further damage. (d) "That the Council be requested to consider whether a memorial should be presented to Her Majesty's Government, urging them to undertake and supervise agricultural experiments, and to procure further and more complete agricultural statistics." The Council have considered the question, and are not prepared to memorialize the Government on the subject. The question of the re-arrangement of the journal has been brought before the Council by Mr. J. B. Martin, and, after careful consideration, the Council are of opinion that it is unnecessary to print in each number of the journal the list of the papers read on the previous day; also that it would be well to place the list of officers of each Section at the head of the list of papers to be read in that Section. The Council wish to obtain the sanction of the General Committee to these alterations. The Council having considered a letter addressed to them by Mr. R. H. Scott, are of opinion that it should be an instruction to the secretaries of all committees, other than committees of Sections, to send notices of all meetings to each member of a committee, and that the draft report of the committee should first be sent in proof to each member, and then submitted to a meeting of the committee specially called for the purpose. The Corresponding Societies Committee, consisting of Mr. F. Galton (chairman), Prof. A. W. Williamson, Sir Douglas Galton, Prof. Boyd Dawkins, Sir Rawson Rawson, Dr. J. G. Garson, Dr. J. Evans, Mr. J. Hopkinson, Prof. R. Meldola (secretary), Mr. W. Whitaker, Mr. G. J. Symons, and General Pitt-Rivers, having by an oversight not been re-appointed at Birmingham last year, the Council have requested these gentlemen to continue the work of their committee, and now nominate them for re-election, with the addition of the names of Mr. W. Topley, Mr. H. G. Fordham, and Mr. William White. In accordance with the regulations the five retiring members of the Council will be Mr. W. Pengelly, Sir Richard Temple, Dr. De La Rue, Sir F. J. Bramwell, and Mr. J. C. Hawkshaw. 
The Council recommend the re-election of the other ordinary members of the Council, with the addition of the gentlemen whose names are distinguished by an asterisk in the following list:-Capt. W. de W. Abney, F.R.S., Sir R. S. Ball, F.R.S., W. H. Barlow, F.R.S., W. T. Blanford, F.R.S., W. Crookes, F.R.S., Prof. G. H. Darwin, F.R.S., Prof. W. Boyd Dawkins, F.R.S., Prof. J. Dewar, F.R.S., *Sir James Douglass, F.R.S., Prof. W. H. Flower, F.R.S., Dr. J. H. Gladstone, F.R.S., Lieutenant Colonel H. H. GodwinAusten, F.R.S., Prof. O. Henrici, F.R.S., Prof. J. W. Judd, F.R.S., J. B. Martin, F.S.S., Prof. H. McLeod, F.R.S., Prof. H. N. Moseley, F.R.S., Admiral Sir E. Ommanney, C.B., F.R.S., Prof. W. C. Roberts-Austen, F.R.S., *Prof. Schuster, F.R.S., *Prof. H. Sidgwick, *Prof. Schäfer, F.R.S., W. T. Thiselton-Dyer, C.M.G., F.R.S., Prof. T. E. Thorpe, F.R.S., *H. Woodward, F.R.S.

Sir H. E. Roscoe, M.P., moved, and Sir R. W. Rawson seconded, the adoption of the report. The motion was adopted.

The Chairman submitted the treasurer's report, which stated that the receipts for the past year were $£ 508 \mathrm{I} 6 \mathrm{~s} .3 \mathrm{~d}$., including a balance of $£ 1869$ brought forward at the Birmingham meeting. The disbursements included the sum of $£$ II 86 r 8 s. in respect of grants in aid of scientific research. The balance in. hand was $£$ i7 I 8 . The report was adopted.

\section{SECTION B.}

CHEMICAL SCIENCE.

Opening Adnrfiss by Edward Schuncr, Ph.D., F.R.S., F.C.S., PRESIDENT OF THE SeCtron.

IT is, I can assure you, with a feeling of extreme diffidence that I take the chair to-day as President of the Chemical Section at this meeting of the British Association. When I look round me and see the many distinguished men who are prepared to take part in our proceedings I c nnnot but very strongly feel that the Council's choice might have fallen on a worthier representative of chemical science than myself. Having in the course of my career bestowed more time and attention to technical matters than to purely scientific subjects, and having moreover arrived at a time of life when active participation in work of any kind must necessarily be drawing to a close, you must not expect from me the accurate knowledge of the present state of chemical science and the questions that are at this moment presenting themselves for solution such as would naturally be required from anyone occupying the post which I have on this occasion the honour to hold. The marvellously rapid progress of chemistry during the last twenty years has made it difficult for the most industrious cultivator of the science to keep abreast of the knowledge of the day, and for a dilettante like myself one may say it is next to impossible. I confess myself painfully conscious of my defec's in this respect, and I shall therefore have to claim the indulgence of the Section should questions arise on which $I$ am unable to speak with authority, or even to discuss with advantage.

Considering, however, how efficiently I am supported by the gentlemen with whom $\mathrm{I}$ have the honou: to be associated, and to whom I am sure in any case of difficulty I may appeal for assistance, I trust to be able to perform the duties of my office without discredit. I will not, however, trouble you with merely personal questions, which are always more or less tedious, but proceed with the few remarks which I wish to make, and which, if not new or instructive, may perhaps serve to entertain you during the time usually devoted to addresses of this kind.

I think you will hardly expect me, even were I fully competent to do so, to review the progress of chemistry during the last half-century, for the time at my disposal would be too short and the result at my hands, I fear, unsatisfactory. I shall prefer to call attention in a few words to the chemistry of other days as I knew it, and the chemistry of the present time as known to us all, and to point out what I consider to be the chief characteristics of each. I shall then, with your permission, point out a few of the directions in which, in my opinion, the chemistry of the future will probably be developed, and in this undertaking I shall perhaps be more successful than in the other; for to discuss the history of science requires exact knowledge; but in specu- lating on its future the imagination comes into play, and to imagine is easier than to describe.

When I first entered on my studies, exactly fifty years ago, chemistry could hardly be called a science-it was rather a collection of isolated facts unconnected by any consistent theory covering the whole field. Most of the important elements were known, but of the exact proportions in which they combine together we were ignorant. The law of definite proportion had been generally accepted, but so imperfect were the data then at our disposal that we may say the law was rather taken for granted than proved. The atomic theory of Dalton as explaining this law had also been adopted by chemists; but it is not unlikely that this theory, then in its infancy, might by the vigorous onslaught of a man of Berthollet's acumen have been upset, and we should then have been left entirely without a guide through the bewildering labyrinth of facts. Of any connexion between chemistry and physics there was in those days no question ; of any but the most superficial notions regarding the effects of heat, light, and electricity on chemical substances we had no conception. The idea that chemistry could have any bearing on or connexion with physiology or pathology would have been ridiculed as absurd. I cannot think of the tben state of organic chemistry without feeling amused. The state of this branch of chemistry could hardly perhaps be called chaotic or rudimentary, for, after all, what had been done had heen well done and neatly done, but the assemblage of facts of which it consisted was devoid of systematic arrangement; it resembled a cabinet of curiosities, the components of which stand in no recognizable relation to one another, or a miscellaneous collection of books placed in an orderly manner on shelves, but without any attempt at classification. As to the genesis of organic compounds, what would now be called absurd notions prevailed. I distinctly remember eminent chemists maintaining that no strictly speaking organic body, even of the simplest constitution, could possibly be formed without the intervention of the so-called vital force. The fact, then recently discovered by Wöhler, of the artificial formation of urea from inorganic substances, was considered as something almost miraculous--i.e. as a phenomenon the like of which would never again recur. Without, however, entering into further de. tails, I think I may, without fear of contradiction, assert that the main distinction between the chemistry of fifty years ago and the chemistry of the present day convists in this, that whereas formerly the science dealt chiefly with qualitative reactions, it now occupies itself principally with quantitative determinations. To have established the fact that every chemical phenomenon may be represented in figures, denoting either number, measure, or weight, such figures, when once accurately determined, remaining constant and unchanged through all time-this seems to me the crowning glory of modern chemistry. It is the firm establishment of this principle that has transformed the face of chemistry and has changed it from a mere descriptive into an exact science.

In justice to our predecessors it should, however, be remembered that this principle, though more fully developed in our own day, was not for the first time set up in quite recent times. The labours of Dalton, conducted on quantitative lines, were performed in this city of Manchester in the early part of thi century. At the same time Berzelius was engaged in analyzing the most important inorganic compounds and establishing the fact, not previously recognized, strange as it may now appear, that every well-defined substance has a definite chemical composition. But going still further back, we come to the alchemists. Now alchemy, if it has any logical basis at all, is founded on quantitative notions as regards matter. All metals, the alchemints said, consist of sulphur, salt, and mercury (these terms signifying not so much elements in the modern sense as qualities) in various proportions; hence their convertibility. Take copper, remove from it a certain proportion of its sulphurous constituent, anc add more of the mercurial, and you have silver; repeat the process with silver, and gold results. At the time of which I speak, though much important analytical work had been done by Berzelius, Rose, and others in organic chemistry, though the veteran Chevreul had led the way in placing organic chemistry on a quantitative basis, and the composition of the most $i$ mportant organic compounds-thanks to the labours of Liebig and his method of organic analysis-had been ascertained, still quantitative determinations were not considered of such paramount importance as at present. In fact, scientific thought did not run in that direction, but satisfied itself, for the most part, with the study of qualitative reactions. It was still possible to see 